\title{
System and History: A Critique of Russian Formalism
}

\section{John Frow}

The theoretical development of Russian Formalism, and of its structuralist successors in Prague, is the record of an exemplary attempt to fuse an immanent approach to the literary text and the literary system, which would locate significance in the structure of textual relations and not in genetic or mimetic features, with an awareness of the essential historicity of these relations. Implicit in the concept of literary evolution is a theory of the mechanism of change - that is, of the connection between literary history and history, and between the text and the social formation; but this theory was never adequately elaborated, both because of a refusal to postulate a direct causal connection between historical change and the apparently autonomous development of the literary system, and because of the Formalists' almost constant separation of aesthetic from extra-aesthetic functions (a separation which confirms the hiatus between the literary series and the social system into which it is inserted). Nevertheless, despite this incompleteness, and despite the extent of the Marxist critique of the Formalist School, ${ }^{1}$ its methodological bases can provide a useful lever for overcoming the dichotomy of intrinsic (formal or literary) and extrinsic (social or contentual or ideological) values.

Particularly in its later phases, the Formalist school worked towards a dynamic conception of the temporal field in which the literary text is situated; this field is constituted by the unity of the diachronic and synchronic systems to which the text belongs, that is, by the fact that every diachronic series is at each moment determined by the systematic configuration of elements at that moment, and that conversely

the synchronic structure of the work includes diachrony in that it carries within itself as a negated or cancelled element those dominant 
modes of the immediately preceding generation against which it stands as a decisive break, and in terms of which its own novelties and innovations are understood. ${ }^{2}$

The text is not seen as an object but as a process, and our attention is not directed to the achieved finality of the work but to the transformational structure of textual production and reception; this structure integrates the work into a series of three moments: production, automatisation, and defamiliarisation (new production), so that the historical dimension of the work involves not only its past (the norms against which it reacts) but its future (the transformation of norm-breaking features of a work into a new norm). Thus 'Pure synchronism now proves to be an illusion: every synchronic system has its past and its future as inseparable structural elements of the system', and the opposition of the concepts of system and of evolution 'loses its importance in principle as soon as we recognise that every system necessarily exists as an evolution, whereas, on the other hand, evolution is inescapably of a systematic character' ${ }^{3}$ But perhaps even more important than this attribution of a diachronic depth to the concept of system is the Formalists' stress on deviation from the aesthetic norm as the central factor in literary evolution (as Striedter points out, ${ }^{4}$ this is directly contrary to the New Criticism's emphasis on the norm itself). What is immediately valuable about this is that artistic value is no longer measured by the optimal fulfillment of the norm (a notion which underlies all those theories which view the 'great artist' as one who is most expressive of the consciousness of his class or society, who corresponds most adequately to its ideological needs); rather, the literary norm is associated with the automatised and the canonic, and 'linear' succession, the maintenance of the norm, is reserved for the merely reproductive activity of literary schools and of epigones. ${ }^{5}$ The function of the reigning literary norm is thus inherently ambiguous: it is at once the recognised and sanctioned standard of literary production, and yet - precisely because of this - at the moment of its ascendancy it has lost its cognitive value, has become 'formalised', an empty shell.

The theory of literary evolution which was developed from the view of new creation as a destruction of the canonic state of the literary system (a destruction which is always a determinate negation, insofar as the negated norm leaves its trace within the new construct, so that the history of the form is present as a kind of accretion of broken prohibitions within the new work) runs directly counter to the classical concept of literary history as a continuous linear process moving through the homogeneous 'objective spirit' or 'style' or 'sensibility' of unified epochs. Writing against such an organicteleological concept of 'evolution' Tynjanov says that

when people talk about 'literary tradition' or 'succession' ... they usually imagine a kind of straight line joining a younger representative of a given literary branch with an older one. As it happens, things are much more complex than that. It is not a matter of continuing in a straight line, but rather one of setting out and pushing off from a given point - a struggle ... Each instance of literary succession is first and 
foremost a struggle involving a destruction of the old unity, and a new construction out of the old elements. 6

The notion of struggle indicates the disjointed and discontinuous nature of change within the literary system, and Wellek goes so far as to see a Hegelian element in this conception: 'Dialectics replaces the principle of continuity. Sudden revolutionary changes, reversals into opposites, annulments and, simultaneously, preservations constitute the dynamics of history'. ${ }^{7}$ The comparison is interesting but probably of limited value, because the literary historiography of the Russian Formalists is marked by an absence of the Hegelian sense of teleology; if reaction and deviation are the motor-force of literary change, there can be no question of a goal, or even necessarily of a congruence with other areas of human activity.

But even if we can posit a large degree of autonomy for the literary series, nevertheless the 'specifically literary' processes of change within the series are still social phenomena. It is the Formalists' inability - and not only in the early stages of the school's development - to go beyond a mechanistic conceptualisation of the processes of automatisation and defamiliarisation (ostranenie) which constitutes their major theoretical weakness.

These two concepts (automatisation and ostranenie) were elaborated as part of the original attempt by the Formalists to isolate the specificity of the literary work, its 'literariness' (literaturnost); the automatic, rigidified language of everyday speech, with its reliance on ellipsis and cliché, was opposed to the 'defamiliarised' language of poetry, a language which is 'perceptible' because of its strangeness and difficulty. Šklovskij provides a theoretical framework for this opposition by setting it in psychological terms:

If we start to examine the general laws of perception, we see that as perception becomes habitual, it becomes automatic... Such habituation explains the principles by which, in ordinary speech, we leave phrases unfinished and words half-expressed. In this process, ideally realised in algebra, things are replaced by symbols. ${ }^{8}$

This statement is based on the assumption that the language of literature should aim at a direct 'seeing' of 'things', and that, therefore, the mediation of the alien material of the sign is the mark of an impaired 'seeing' - of an automatised 'recognition'. On the other hand, however, Sklovskij is unwilling to be forced into the position of regarding this signifying material as something separate from and secondary to the denoted 'content'. The ambiguity of his attempted reconciliation of these two different conceptions becomes apparent from the vagueness of reference with which he endows his central category: as Jameson notes, 'Ostranenie can apply either to the process of perception itself, or to the mode of presentation of that perception'. ${ }^{9}$ Sklovskij's argument culminates in this passage:

The purpose of art is to impart the sensation of things as they are perceived and not as they are known. The technique of art is to make objects 'unfamiliar', to make form difficult, to increase the difficulty and length of perception because the practice of perception is an 
aesthetic end in itself and must be prolonged. Art is a way of experiencing the artfulness of an object; the object is not important. ${ }^{10}$

The confusion here stems from Šklovskij's inability to distinguish between everyday perception, directed more or less immediately to 'the object', and aesthetic 'perception', which is directed to values; by equating the signified of the work (i.e. an image constructed wholly within the limits of its language) with a referent in the real world, he is compelled to project the 'artfulness' of art outwards, onto 'the object', and yet simultaneously to endow this empirical substance with an aesthetic quality, a quality of 'form', which pre-exists the work of art. This hypostatised quality properly belongs neither to the work nor to the empirical world but is caught in a limbo between them.

There is thus a tension between two aspects of Sklovskij's thesis: on the one hand there is the psychological concept of the 'estrangement' of automatised perception and the creation of a new vision of the world (a concept which misses the interplay between automatised literary forms and everyday perception); on the other hand, as an incompatible alternative to this view, 'perception made difficult by estrangement is directed to the estranging form itself'. ${ }^{11}$ Elsewhere Sklovskij writes that "' artistic" perception is a perception that entails awareness of form (perhaps not only form, but invariably form)'. 12 The parenthetical 'not only' betrays, again, the failure to theorise clearly the relation between form and content, or rather to transeend clearly the relation between form and content, or rather to transcend the demarcation between the intra- and the extra-aesthetic. This later absolute stress on 'form' is a further attempt to resolve the dichotomy by simple reduction: thus he writes of Sterne: 'By violating the form, he forces us to attend to it; and for him this awareness of the form through its violation constitutes the content of the novel'. ${ }^{13}$ But form now becomes an end in itself, and Šklovskij cannot conceive of the self-referentiality of a text as more than a 'play' with technical elements - that is, he cannot see the norm and the breaking of the norm as phenomena which refer to more general modes of social authority. Šklovskij limits the concept of form to purely constructional devices; he excludes the whole range of thematic material and the concept therefore tends to be mechanical. ${ }^{14}$

Similarly, the Formalist theory of the immanent dialectic of automatisation and estrangement treats this dialectic as a quasi-automatic process. ${ }^{15}$ To quote Šklovskij again:

... a work of art is perceived against a background of, and by means of association with, other works of art. The form of the work of art is determined by the relation to other forms existing before it . . . Not only a parody, but also in general any work of art is created as a parallel and a contradiction to some kind of model. A new form appears not in order to express a new content, but in order to replace an old form, which has already lost its artistic value. ${ }^{16}$

The accentuation of the primacy of intertextual relations, and their role in motivating systematic change, is important and fruitful as far as it goes, but 
the interesting phrase here is the last one: the word 'lost' suggests a natural process, as though the change in artistic value were organic and not governed by changes in the work's reception. Tynjanov - despite his concern for the historical situation from which change emanates - is capable of an even more mechanistic conception of the process of literary evolution; he defines the four following stages:

(1) In connection with the automatised constructional principle a dialectically opposite constructional principle appears; $(2)$ this constructional principle seeks out its easiest application; (3) it is extended to the largest possible number of phenomena; (4) it becomes automatised and elicits opposing constructional principles. ${ }^{17}$

This reads almost like a parody in its stress on the objectivity of a sequence of purely technical developments. Medvedev relates this notion (which, however, is not predominant in Tynjanov's best work) of the literary system as an 'objective fact', independent of the subjective consciousness of the producer and recipient of literary works, to the Formalists' reaction against a psychologistic aesthetic and the naive interpretation of the work as an expression of an 'inner world', a 'soul'; but he observes that in the process of this reaction, "The work is cut off from both real social realisation and from the entire ideological world'. Ideology is identified as an individual-subjective fact rather than as an objective system, and so 'while liberating the work from the subjective consciousness and psyche, the formalists at the same time estrange it from the whole ideological environment and from objective social intercourse'. ${ }^{18}$ As a consequence of this, the theoretical basis of Formalist theory remains trapped in the presuppositions of its opponents:

In severing literature from the ideological world, the formalists turned it into some kind of stimulus for relative and subjective psychophysical states and perceptions.

For their basic theories - deautomatisation, the perceptibility of the construction, and the others - presuppose a perceiving, subjective consciousness. ${ }^{19}$

The Formalists' understanding of literary evolution as a process which is immanent to the literary system and based primarily on intertextual relations has two consequences. The first is that the study of literature is seen to require a sharp separation between literary and extra-literary factors, and that the latter are (with only apparent exceptions) rigorously excluded from consideration; Ejxenbaum, for example, in his reply to Trotsky will speak of an absolute separation of the fields of competence of Marxism and formal analysis, since the genetic field and symbolic creation belong to two distinct orders of being which are irreducible to each other. ${ }^{20}$ Furthermore, as long as there can be no mediation between the literary and the ideological systems, 
the phenomenon of intertextuality must be deprived of its social dimension (its relation to the 'extra-literary') and regarded as a more or less self-motivating process. The second consequence, however, is a broadening and generalisation of the evolutionary moment:

Since every work of art can only appropriately be perceived as form, but every form only as a 'differential quality', as a deviation from a 'dominant canon', then the pre-given material must always be taken into account at the same time, 21

and therefore the literary-historical aspect becomes a necessary component of formal analysis.

Tynjanov's concept of system permits a more complex understanding of the relation of formal elements to literary-historical change land thus, eventually, to historical change). The concept is applied at three levels: first that of the literary work, which can now be seen, not (as in the early writings of Sklovskij) as an aggregate of artistic devices (with the corollary that literary evolution involves a mere substitution of devices), but as a structured and functional system, a 'regularly ordered hierarchical set of artistic devices' 22 (with evolution therefore being seen as a shift in this hierarchy). Secondly, the work-as-system refers to the synchronic literary system in which it is situated (and to the diachronic series from which this system was formed). The elements of the work function simultaneously within both these orders, and their intra-textual function is overdetermined by their intertextual function:

An element is on the one hand interrelated with similar elements in other works in other systems, and on the other hand it is interrelated with different elements within the same work. The former may be termed the auto-function and the latter, the syn-function. ${ }^{23}$

Central to the intertextual dimension of these elements is the literary genre which mediates between the work and the total system of a period; the genre forms in effect a sub-system of the literary system; it exists only as evolution, is the immediate 'dominant' of the work, and organises the elements of the work according to both their syn- and their auto-function. ${ }^{24}$ The third application of the concept of system is to the differential relation between the literary system and extra-literary reality conceived of as an ordered set of systems (the totality of the social formation is thus a 'system of systems'). This relation is equally determinant of the mode of being of formal elements: 'The very existence of a fact as literary depends on its differential quality, that is, on its interrelationship with both literary and extra-literary orders. Thus, its existence depends on its functions' ${ }^{25}$ This view of the dialectical determination of formal elements, through their simultaneous integration in disparate functional systems, allows Tynjanov to posit inter-system influence as a moment of system change, and even to come close to connecting this inter-system moment with the principle of deviation from an automatised norm which is at the heart of his theory of literary evolution: 'The very concept of a continuously evolving synchronic system is con- 
tradictory', since 'a literary system is first of all a system of the functions of the literary order which are in continuous interrelationship with other orders' ${ }^{26}$ Literary evolution is based neither on a purely immanent development, nor on a strict 'determination' by other orders, but is a process of constant uneven modification of literary by extra-literary functions and vice-versa.

In effect, the correlation of literary ('constructional') function with extraliterary functions, which is achieved through the correlation of different interlocking systems, makes possible the establishment of a theoretical plane where facts of the same order can be mediated. This is evident from the fact that the concept of system is used in the same way to assess the interaction of the synchronic literary system with previous literary systems and with other systems: both enter systematically (and in ways which we might guess to be connected) into the determination of the 'intrinsic' function of textual elements, and it is in this sense that Tynjanov and Jakobson write that

the evolution of literature cannot be understood until the evolutionary problem ceases to be obscured by questions of episodic, non-system origin, whether literary (for example, so-called 'literary influences') or extraliterary. The literary and extraliterary material used in literature may be introduced into the orbit of scientific investigation only when it is considered from a functional point of view. 27

It is worth noting that the 'extra-literary' is used by Tynjanov to mean not only extrinsic forces and situations influencing the function of constructional elements (e.g. the genetic situation of the work), but also the thematic 'content' of the work; however, Tynjanov refuses to draw a sharp distinction between formal elements and 'external' material: 'the concept of material does not extend beyond form - it too is formal; its confusion with extraconstructional factors is a mistake' ${ }^{28}$

A further guarantee that it is facts of the same logical level which are being mediated is the principle that 'The study of evolution must move from the literary system to the nearest correlated systems, not the distant, even though major systems', ${ }^{29}$ and this means in the first place a movement 'from literary function to verbal function'. ${ }^{30}$ Extending this slightly, it is through verbal function that literature is related to behavioural norms:

Social conventions are correlated with literature first of all in its verbal aspect. This interrelationship is realised through language. That is, literature in relation to social conventions has a verbal function. ${ }^{31}$

By using language as the 'nearest correlated system' Tynjanov comes close to something like the notion of an 'intertextual' relation to the extra-literary realm, a relation of like to like (and this is why the relation of form to 'material' is not a stumbling-block for Tynjanov as it is for Šklovskij).

However, when Tynjanov attempts to specify what he means by intersystemic determination, the examples he gives are relatively trivial. He speaks, for instance, of the interrelationship of social convention with literature as constituting the 'orientation' of a work, and cites the declamatory ode (which 
is intended for public recitation) as having an oratorical orientation..$^{32}$ But this is to restrict inter-systematic influence on literary function to extremely narrow limits, by confining it to the empirical speech-situation of the work. It is virtually the kind of genetic reduction which Tynjanov deplores in his opponents, and it is 'formalist' in the bad sense, i.e. in its equation of the extra-literary with the work's 'context' rather than with other modes of discourse, and in its exclusion of thematic factors. Even where he thinks of the determination of literary function in terms of an appropriation of extraliterary into literary discourse (e.g. the incorporation of the letter-form into the eighteenth-century novel), this is still only a relatively minor part of what he conceives to be the process of literary evolution: it is the 'positive' side of evolution; but the fundamental dynamic of literary change occurs through an intertextual reference which is negative; the process involves not only the incorporation of non-canonic discourse but the rejection of canonised discourse. In other words, by neglecting this negative dynamic, Tynjanov shows himself to be incapable of linking together extra-literary determination with the processes of automatisation and reaction against the automatised norm. We are left with a disjunction between intertextual and intersystemic relations, a final unmediated dualism: on the one hand, the diachronic relationship of functional elements to elements in other literary systems, on the other hand, the relationship between literary and extra-literary functions. The reason for this failure of mediation lies in Tynjanov's inability to conceive of the literary norm as a phenomenon which is simultaneous/y a 'specifically literary' and a social fact, i.e. his inability to grasp the immanence of the social order within the literary order; as long as automatisation and ostranenie are seen as 'automatic' processes, he cannot conceptualise norm-formation and norm-breaking as socially-determined changes in the literary system.

We could put this differently by shifting the critique of Tynjanov's theory to his notion of the 'system of systems' as a set of contiguous orders. ${ }^{33}$ The justification of this notion is well expressed by Ehrlich:

The view of the social fabric as a 'system of systems' substituted the postulate of correlating various self-evolving series for the insistence on reducing the secondary sets of data to the primary ones. ${ }^{34}$

But what is surprising here is that this view violates the theory, first formulated by Jakobson and adopted by Tynjanov, of the system (hence also of the system of systems) as a hierarchically ordered set of factors which is structured by a dominant. ${ }^{35}$ If we compare this theory with Althusser's notion of the 'structure à dominante' (and the similarity is such that there may well be a direct connection between the two), it becomes evident that the weakness of Tynjanov's view of a set of merely juxtaposed series is that it cannot account for the overdetermination of the total system by the structure of social power (by the structure of social relations of production and reproduction). This, of course, is not the same thing as a reduction of superstructural systems to a 'primary' system. It follows logically from this that Tynjanov will be unable to account for the authority of the automatised norm in terms of the control of symbolic production by a hegemonic class, 
nor to see deviation from the norm as anything more than a 'specifically literary' phenomenon. Indeed, for Tynjanov the whole sphere of literary production and reception is completely isolated from any intervention by the institutions of symbolic control - the School, the salon, the Church, the agencies of reproduction, etc., i.e. the institutions which determine the reception, dissemination and legitimation (or rejection) of the literary product. It is this which influences his choice of language as the 'neighbouring order': unlike the concept of ideology, the concept of language is relatively undifferentiated with respect to the overdetermination of the superstructure by the system of social power-relations; it lends itself more readily to the division into literary/non-literary discourse than to an articulation of values which would cut evenly across both these discursive areas.

\section{III}

After the silencing of the Formalist movement in the early Stalinist period, many of its theoretical insights were taken up and modified by members of the Prague Linguistic Circle. In particular, the concept of function was further developed by Jakobson and Mukařovsky. Jakobson isolates an 'aesthetic function' which marks literary language off from the rest of language: 'poetry is language in its aesthetic function', 36 and the object of a science of literature is not 'literature' but literariness, the aesthetic function which constitutes a work as a literary work. However, the presence of this function is not a simple presence. The poetic work fulfills 'neither an exclusively aesthetic function nor an aesthetic function along with other functions; rather, a poetic work is defined as a verbal message whose aesthetic function is its dominant'. 37 Whilst 'poeticality' is only one component of a complex structure, it is 'a component which necessarily transforms the other elements and in conjunction with them determines the behaviour of the whole'. 38 Jakobson defines the working of the aesthetic function against the referential and affective functions of non-literary language; it is manifested

In the fact that the word is experienced as a word and not as a simple substitute for the object named nor as an explosion of emotion. In the fact that words and their syntax, their signification, their external and internal form, are not casual indices of reality but have their own weight and their own value. 39

He insists, finally, that he, Tynjanov, Mukařovsky and Šklovskij do not abstract art from its social context but are aware of the dialectical interrelationship between art and other sectors of the social structure. 'What we emphasize is not a separatism of art but the autonomy of the aesthetic function'.40

The danger, however, with notions like those of 'literariness' and of an 'aesthetic function' is that, instead of referring to the historical and structural concept of the literary system (as an institutionalised set of expectational 
norms governing the production of new texts), they can tend to hypostatise a 'quality' which resides in the work, to treat an analytic fiction as an essential property. This is quite clearly evident in Mukarovsky's conception of the aesthetic function, despite his disclaimer to the contrary. ${ }^{41}$ The basis for the distinction between aesthetic and extra-aesthetic function is, again, the differentiation between the communicative and the artistic functions of language, 42 that is, 'between a self-referential phenomenon (poetry) and one that is communicative (aimed at emotions)' ${ }^{43}$ Mukarovsky is, of course, careful to stress that there can be no rigid separation between practical and poetic language; one can posit no more than the dominance of a particular function, side by side with other subordinated functions, 44 and Günther interprets Mukarovsky's theoretical standpoint here to be that

poetic language ... is distinguished by the 'displacement of the centre of gravity' from the referential function of words to their insertion in the composition of the poetic sign, although without the communicative functions being excluded. 45

But this still doesn't fully clarify the way in which the poetic sign manages to signify simultaneously in two different ways. The whole concept of function remains ambivalent in Mukarovsky's writings insofar as it denotes a quality inherent in language or in an artefact; when he writes, for example, of the gradual passage from non-aesthetic to aesthetic function in churches or in scientific texts, 46 he is not concerned with the social determination of this passage but treats it as the mutation of an inner dynamic in the object. Function is not conceived of as a use to which something is put, nor can we ask how the aesthetic function actually 'functions'. What is involved here is essentially a hypostatisation of the aesthetic realm, an unwillingness to explore the consequences of the notion of function. The opposition which Mukarovsky works out between 'instruments' and 'art-works' similarly fails to grasp that the aesthetic, in its very lack of direct instrumentality, develops its own specific kind of instrumentality; Mukarovsky cannot think of the self-referentiality of art, and the consequent semanticisation of form, as in any way a 'relationship to reality' (since the realm of art is ultimately unconnected with 'reality').

The relation between aesthetic and extra-aesthetic value is treated by Mukarovsky in two different theoretical contexts. The first deals with the interaction of the aesthetic 'series' with the rest of the social formation. Following Tynjanov (and laying himself open to the same objections), Mukarovsky argues for a notion of the non-dominated contiguity of autonomous social structures:

The realm of social phenomena, to which literature belongs, is made up of a number of series (structures), each of which has its own autonomous development: these would include science, politics, the economy, social stratification, language, morality, religion, etc. Despite their autonomy, however, the individual series mutually influence each other. 47 
By means of this vaguely expressed 'mutual influence' aesthetic value is determined both by the 'immanent development of artistic structure' and by the 'motion and shifts in the structure of social life', 48 and the postulate of autonomy (and the fact that the 'artistic structure' is apparently separate from 'social life') ensures that there can be no interconnection between the two factors. In a second context, Mukarovsky discusses the relation of aesthetic to extra-aesthetic values within the work, and draws the conclusion that the work is effectively a collection of extra-aesthetic values. Thus,

if we ask ourselves at this point what has happened to aesthetic value, it appears that it has dissolved into individual extra-aesthetic values, and is really nothing but a general term for the dynamic totality of their mutual interrelationships. The distinction between 'form' and 'content' as used in the investigation of an art-work is thus incorrect -

because 'all elements of a work are, without distinction, components of form', and 'all components are equally the bearers of meaning and extra-aesthetic values, and thus components of content' ${ }^{49}$ This apparently dialectical view, however, conceals the same dualism of internal/external, of unmediated intraand extra-aesthetic realms, which I noted in Tynjanov, since value is not created 'internally' in the process of revaluation of the literary norm but is imported into the work. Mukarovsky is in fact aware of the danger of positing the transparency of the artistic construct, and elsewhere draws a further distinction between its immediate function (the manifestation of reality directly through the work, in the form of extra-aesthetic values), and its symbolic function, the self-referential opacity of the aesthetic. $50 \mathrm{His}$ difficulty then is to account for the presence of 'reality' in the latter, since, just as aesthetic value dissolves into individual extra-aesthetic values, so the extraaesthetic functions disappear in a properly 'aesthetic' reception of the work. What this comes down to finally is the problem of the transformation of extra-aesthetic values within the work - a problem which is not resolved by Mukařovsky's reference to aesthetic value as 'the dynamic totality of their mutual interrelationships' - and the problem remains constant as long as there is a question of the induction rather than the production of meaning. Strohschneider-Kohrs, for example, uses Mukarovsky's categories to argue that it is through the subordinated, non-aesthetic functions that the work takes cognizance of the real:

What Mukařovsky calls 'functions', relating to 'extra-linguistic instances and goals', should be understood as literary elements intending, indicating or mediating reality. They bring about the transformation of extra-literary impulses into intra-literary structure. 51

But here too it is the content of a verbal function, not its actual form, which is used as an indicator of the extra-literary; and this content, which is a fixed quantity, is previous and external to the aesthetic function. The logical contradictions in Mukarovsky's theory are emphasised, finally, by the fact that his disciple K. Chvatik can reconcile it, without too much distortion, with vulgar-Marxist doctrine: he relates the concept of the purely organi- 
sational role of aesthetic function to the notion, central to canonic reflection theory, of the transparency of 'form' (by means of which our attention is concentrated on 'the thing itself . . . as it really is'): 52 the poles of formalism and mechanical materialism meet at their extremes.

Perhaps the most important lesson we can draw from the limitations in Russian Formalist theory is the importance of establishing the unity of the conceptual level at which 'extra-literary' values and functions become structural moments of a text, and at which, conversely, the 'specifically literary' function acquires an extra-aesthetic dimension. To some extent this may be a question of being sufficiently 'formalist', i.e. of being willing to relate the literary sign to other signs (to the structured order of the semiotic field) rather than to a reality which transcends the sign; to relate literary fictions to the universe of fictions rather than to the non-fictive universe. This correlation can best be effected by using the ideological system as the 'neighbouring order' with which the literary system is cognate and in which it is partially inserted. The reasons for this choice would include the following: (1) The ideological structure is made up, as Vološinov has argued, both of ideological themes (the signifieds which we are used to thinking of as the 'content' of literary texts) and of ordered modes of organisation of these units. There is thus a difference of degree but not of kind between the 'form' and the 'content' of signification. Insofar as literature is inserted in the ideological structure, its conventional and 'autonomously developed' forms carry an ideological weight. (2) The 'relative autonomy' of the literary system within the ideological system means that we can posit the essentially intertextual determination of literary change without ceasing to regard this as being, through a series of mediations, a social determination. (3) The concept of ideology permits a direct relation of the literary system (and its evolution) to the structure of power in a social formation, because it contains an inner principle of differentiation according to the relative and historically changing control exercised by the hegemonic and the subordinated classes over the process of social reproduction. (4) The concept of ideology also permits us to theorise the movement of the literary system (its production and reception) in terms of reaction and of discontinuity, rather than in terms of a correspondence or homology between the literary and the social structure. The central Formalist concept of the negative dynamic of literary evolution makes it possible to escape that historicism which can only perpetuate itself on the basis of metaphor and intuition.

The decisive question then becomes that of the way in which we can establish the differential unity of literary and ideological norms. This question can only be answered dialectically and historically (otherwise we fall into the trap of arguing simply for or against the ideological nature of literary products); but in a sense the answer is already implicit in Formalist theory, 
and specifically in the concepts of automatisation and ostranenie. If we can discard the notion of automatisation as a purely automatic process, and see it instead as the effect of a revaluation of the work brought about by its 'inscription in social contradictions', 54 i.e. as a moment of its reception, then we can work towards an understanding of the mechanism of this process. The Formalists tend to separate the moments of canonisation and automatisation, but clearly the two are intimately connected; and this suggests (given the control by the hegemonic class over the institutions of legitimation) that automatisation is effectively a consequence of the adoption or sanctioning of a literary product by the ruling class (or its ideological representatives). The automatised work is a work which has been legitimised, and thus has been appropriated into the sphere of the ideological. What is important here is that we conceive of this ideological state not as a fixed quality in a text but as a result of the position assigned to it in relation to the ideological structure; thus a work will mean differently and different things at different times, according to its more or less canonic status.

The literary norm, therefore - the dominant and legitimate formal and thematic features in a given synchronic system - will represent the actual ideological state of the system. Normative value will be held by (1) the 'classical' texts; (2) writers who have attained 'official' recognition; (3) their epigones; (4) writers in the 'low' genres (e.g. the mass-media) working within dead traditions. This is a very schematic description, and obviously the real distribution of ideological authority is somewhat more complex (for example, there is a constant possibility of using the 'classical' texts against the grain of their official status - e.g. Kafka's use of Dickens; 'official' recognition is usually based on distortion, and is usually incomplete, so that a writer may well survive his laurels; and although 'low' genres tend to function anachronistically, they tend also to provide the impetus for new directions within the 'high' genres - cf. Robbe-Grillet's or Etienne Leroux's use of the detective novel). Nevertheless, in principle we can assume a direct connection between canonisation and the investiture of a work with ideological value. The agents of this investiture are the ideological institutions (the School, the Church, the media, the salon ....), supported by the activity of epigones, and their task is primarily to neutralise the new product; as Foucault expresses it:

In every society the production of discourse is at once controlled, selected, organised and redistributed according to a certain number of procedures, whose role is to avert its powers and its dangers, to cope with chance events, to evade its ponderous, awesome materiality. 55

The control of discourse - its neutralisation, automatisation - implies removing the work from its real historical time and situating it in the universal second nature of ideology; it becomes a part of the cultural habitus, 56 becomes 'familiar' and so, gradually, imperceptible. ${ }^{57}$ This process is equivalent to an injection of ideological meaning into the work: that is, the meaning of the 'aesthetic object' is altered as its situation vis-à-vis the ideological field changes. The object of interpretation can therefore never be a static object, but can only be a process or a moment of literary evolution (and to suppose 
a fixed and objective signification or a 'universal' value is to take at face value the illusory 'second nature' into which the canonised work is inscribed).

As Brüggemann notes, 58 the modes of legitimation are in each case historically variable; the area of dominant normatisation will determine the direction of new production, but in all cases the impetus will be, whether or not the author is aware of it, intertextual: either a replication of the norm (establishing a continuity but not an aesthetic 'value' since real aesthetic cognition is not possible within the framework of a neutralised form), or a break with the norm on the basis of the norm (establishing a discontinuity which is never a pure 'originality', and necessarily involving a new mode of aesthetic cognition). However, given that the literary norm is the result of an intervention of social factors in the 'specifically literary' process of evolution, it now becomes possible to conceive of intertextuality as a phenomenon which simultaneously belongs to the purely literary order and relates to the 'extra-aesthetic' order of ideology.

This is not to deny that literary production is equally a social phenomenon, nor to envisage the act of production as a private or isolated act. However it is methodologically more convenient to locate the moment of greatest extraaesthetic involvement in the literary norm, since production is a variable until it is normalised by incorporation into the ideological structure, whereas the norm is remarkable for its regularity (a result, primarily, of its global dissemination and its aimost complete authority). A further consequence of this argument is that it becomes necessary to posit a gap beween the production of a work and its subsumption into ideology. This assumption is a logical necessity even in those cases where assimilation is immediate, i.e. where an author writes completely within the norm in the expectation of automatic adoption by the ideological apparatus. The theoretical basis for positing this gap is

the distinction between the origin of any cultural fact and its acceptance. In art, for example, all sorts of stylistic variations or mutants appear in any period. The social and political environment acts as a selective agency upon them. 59

In other words, the criterion of ideological status can never be genetic, but must be found in the work's 'inscription in social contradictions'. However, this postulation of a gap between production and automatisation should not be taken to imply a rigid separation between the two, since literary evolution must be conceived of as a unity of the moments of production/automatisation/ new production (so that production can never be divorced from the norm which precedes and motivates it). It should be understood, too, that for the sake of clarity the critical moment of the 'break' has been shifted from the synchronic/structural plane to the diachronic plane and seen as a temporal gap: it is, in fact, a 'moment' in both senses of the word.

The partial insertion of the literary system in the ideological system is, therefore, a constantly changing and constantly (but unevenly) renewed state rather than a fixed descriptive a priori. The concept permits us to theorise the relation of the literary to extra-literary series as a concentration of social 
value with in the former, and to develop a mode of analysis which, rather than isolating the text in its 'specifically literary' autonomy or moving outwards from the text to its non-literary context, can identify social determinations as an intrinsic factor in the text.

\section{Notes}

1. See especially Marxismus and Formalismus, ed. Hans Günther (Munich: Hanser, 1973); and Leon Trotsky, Literature and Revolution (Ann Arbor: University of Michigan Press, 1960).

2. Frederic Jameson, The Prison-House of Language (Princeton: Princeton University Press, 1972), pp.92-3.

3. Jurij Tynjanov and Roman Jakobson, 'Problems in the Study of Literature and Language', in Readings in Russian Poetics, ed. Ladislav Matejka and Krystyna Pomorska (Cambridge, Mass: M.I.T. Press, 1971), p.79.

4. Jurij Striedter, 'Zur formalistischen Theorie der Prosa und der literarischen Evolution', in Russicher Formalismus, ed. Jurij Striedter, 2nd ed. 11969; rpt. Munich: Fink, 1971), p.Ixxi.

5. Jurij Tynjanov, 'Das literarische Faktum', in Russicher Formalismus, p.401.

6. Jurij Tynjanov, quoted in Boris M. Ejxenbaum, 'The Theory of the Formal Method', in Readings in Russian Poetics, p.31.

7. René Wellek, 'The Concept of Evolution in Literary History', in Concepts of Criticism (New Haven: Yale University Press, 1963), p.40.

8. Viktor Šklovskij, 'Art as Technique', in Russian Formalist Criticism: Four Essays, ed. L. Lemon and M. Reis (Lincoln: University of Nebraska Press, 1965), p.11.

9. Jameson, The Prison-House of Language, p.75.

10. Šklovskij, 'Art as Technique', p.12.

11. Striedter, 'Zur formal istischen Theorie ... . p.xxiii.

12. Quoted in Exjenbaum, 'The Theory of the Formal Method', p.12.

13. Viktor Šklovskij, 'Stern's Tristram Shandy', in Russian Formalist Criticism, p.30-31.

14. C.F. Boris I. Arvatov, 'Poetische und praktische Sprache (Zur Methodologie der Kunstwissenschaft)', in Marxismus und Formalismus, p.115: 'Sklovskij has forgotten that form lives not only in art but in every cell of life, and in this respect he has fallen to the same level as his opponents: neither they nor Sklovskij were able to recognize the social nature of form'.

15. C.F. Ingrid Strohschneider-Kohrs, Literarische Struktur und geschichtlicher Wandel (Munich: Fink, 1971), p.13.

16. Viktor Šklovskij, 'The Connection between Devices of Syuzhet Construction and General Stylistic Devices', in Russian Formalism, ed. S. Bann and J. Bowlt, Twentieth Century Studies (New York: Barnes and Noble, 1973), p.53.

17. Tynjanov, 'Das literarische Faktum', in Russischer Formalismus, p.413.

18. Pavel N. Medvedev/Mikhail M. Bakhtin, The Formal Method in Literary Scholarship: A Critical Introduction to Sociological Poetics, trans. Albert J. Wehrle (Baltimore: Johns Hopkins University Press, 1978), p.145.

19. Ibid., p.149.

20. Quoted in Viktor Ehrlich, Russian Formalism, 3rd ed. (1955; rpt. The Hague: Mouton, 1969), p.109.

21. Striedter, 'Zur formalistischen Theorie ... ․ p.xxx.

22. Roman Jakobson, 'The Dominant', in Readings in Russian Poetics, p.85.

23. Jurij Tynjanov, 'On Literary Evolution', in Readings in Russian Poetics, p.68.

24. Striedter, 'Zur formal istischen Theorie ....' p.Ixii.

25. Tynjanov, 'On Literary Evolution', in Readings in Russian Poetics, p.69.

26. Ibid., p.72.

27. Tynjanov and Jakobson, 'Problems in the Study of Literature and Language', 
in Readings in Russian Poetics, p.79.

28. Tynjanov, quoted in Ejxenbaum, 'The Theory of the Formal Method', p.28.

29. Tynjanov, 'On Literary Evolution', in Readings in Russian Poetics, p.77.

30. Ibid.

31. Ibid., p.73.

32. Ibid., p.74.

33. Ibid., pp.73-4.

34. Ehrlich, Russian Formalism, p.135.

35. Jakobson, 'The Dominant', in Readings in Russian Poetics, p.83.

36. Roman Jakobson, 'Fragments de "La Nouvelle Poésie Russe"' in Questions de Poétique (Paris: Ed. du Seuil, 1973), p.15.

37. Jakobson, 'The Dominant', in Readings in Russian Poetics, p.84.

38. Roman Jakobson, 'Qu'est-ce que la poésie?' in Questions de Poétique, p.124.

39. Ibid.

40. Ibid., p.123.

41. Jan Mukařovsky, Aesthetic Function, Norm and Value as Social Facts, trans. M. Suino (Ann Arbor: Michigan Slavic Contributions, 1970), p.3.

42. Jan Mukařovsky, 'Zur tschechischen Übersetzung von క̌klovskij's Theorie der Prosa', alternative No.80 (Oct. 1971), p.166.

43. Mukařovsky, Aesthetic Function, Norm and Value as Social Facts, p.9.

44. Ibid., p.3.

45. Hans Günther, Struktur a/s Prozess (Munich: Fink, 1973), p.20.

46. Jan Mukařovsky, 'Der Standard der ästhetischen Funktion ünter den übrigen Funktionen', in Kapitel aus der Ästhetik (Frankfurt am Main: Suhrkamp, 1970). p.113.

47. Mukăovsky, 'Zur tschechischen Übersetzung von Šklovskij's Theorie der Prosa', p.170; for a critical analysis of the theoretical consequences of this cf. Kurt Konrad, 'Der Streit um Inhalt und Form', alternative No.80 (Oct. 1971).

48. Mukařovsky, Aesthetic Function, Norm and Value as Social Facts, p.67.

49. Ibid., p.88.

50. Mukarovsky, 'Der Standard der ästhetischen Funktion unter den übrigen Funktionen', pp.126, 134.

51. Strohschneider-Kohrs, Literarische Struktur und geschichtlicher Wandel, p.24.

52. Kvetoslav Chvatik, Strukturalismus und Avantgarde: Aufsätze zur Kunst und Literatur, trans. H. Gaertner (Munich: Hanser, 1970), p.88.

53. V.N. Vološinov/Mikhail Bakhtin, Marxism and the Philosophy of Language, trans. L. Matejka and I.R. Titunik (New York: Seminar Press, 1973).

54. Francisco Posada, Lukacs, Brecht y la situación actual del realismo socialista (Buenos Aires: Editorial Galerna, 1969), p.267.

55. Michael Foucault, The Discourse on Language, in The Archaeology of Knowledge (New York: Pantheon, 1972), p.216.

56. Pierre Bourdieu, Outline of a Theory of Practice, trans. Richard Nice (London: Cambridge University Press, 1977), pp.78-87.

57. C.F. Viktor Šklovskij, 'The Resurrection of the Word', in Russian Formalism, ed. Bann and Bowlt, p.44; automatised works 'cease to be seen and begin to be recognised', they 'have become covered with the glassy armour of familiarity'.

58. Heinz Brüggemann, Literarische Technik und soziale Revolution - Versuche über das Verhältnis von Kunstproduktion, Marxismus und literarischer Tradition in den theoretischen Schriften Bertolt Brechts (Reinbek bei Hamburg: Rowohlt, 1973), p.176.

59. Sidney Hook, quoted in Fredric Jameson, Marxism and Form (Princeton: Princeton University Press, 1971 ), p.384. 


\section{University Library}

\section{- M M I E E R VA A gateway to Melbourne's research publications}

Minerva Access is the Institutional Repository of The University of Melbourne

Author/s:

FROW, JOHN

Title:

System and history: a critique of Russian formalism

Date:

1980

Citation:

Frow, J. A. (1980). System and history: a critique of Russian formalism. Oxford Literary Review, 4(2), 56-71.

Publication Status:

Published

Persistent Link:

http://hdl.handle.net/11343/34515 